\title{
Mathematics teachers' reasons to use (or not) intentional errors
}

\author{
RiıkKa Palkki ANd Peter Hästö
}

\begin{abstract}
Mathematics teachers can make use of both spontaneously arising and intentionally planted errors. Open questions about both types of errors were answered by 23 Finnish middle-school teachers. Their reasons to use or not to use errors were analyzed qualitatively. Seven categories were found: Activation and discussion, Analyzing skills, Correcting misconceptions, Learning to live with errors, (Mis)remembering errors, (Mis)understanding error and Time. Compared to earlier results, the teachers placed substantially less emphasis on affective issues, whereas the answers yielded new distinctions in cognitive dimensions. In particular, teachers' inclination to see errors as distractions could be divided into two aspects: students misunderstanding an error in the first place or student forgetting that an error was erroneous. Furthermore, the content analysis revealed generally positive beliefs towards using errors but some reservations about using intentional errors. Teachers viewed intentional errors mainly positively as possibilities for discussion, analysis and learning to live with mistakes.
\end{abstract}

Key words and phrases: learner error, intentional error, beliefs, mathematics teaching, mathematics teachers .

ZDM Subject Classification: C29.

\section{Introduction}

Errors can function as "springboards for learning" (Borasi, 1994; Bray \& Santaga, 2014). From a constructivist perspective, errors are possibilities for cognitive growth through refinement and reorganization, not something to be replaced (Smith III, diSessa, \& Roschelle, 1994). They reveal students' reasoning and enable learning (Brodie, 2014; Santagata \& Bray, 2015). Nevertheless, 
committing an error is often experienced as something negative, shameful and self-threatening (Steuer \& Dresel, 2015). Furthermore, teachers tend to avoid discussing errors in class even though errors would offer an opportunity to find out what to focus on in their teaching (Metcalfe, 2017).

Errors may also be introduced intentionally, as in the case of an example with an erroneous step. This method has been found to be useful for learning (Adams et al., 2014; Booth, Lange, Koedinger, \& Newton, 2013; Durking \& Rittle-Johnson, 2012; Große \& Renkl, 2007). Inspired by such results, we included tasks with intentional errors in a 10-hour long teaching material in a Flexible Equation-solving Project. However, teachers had difficulties engaging with the intentional error task (Palkki, 2016). This led us to the present study of teachers' beliefs about the role of errors and intentional errors in teaching and learning mathematics.

Mathematics teachers inevitably encounter student errors since these occur independent of age or ability (Gagatsis \& Kyriakides, 2000). A misconception means "a student conception that produces a systematic pattern of errors" (Smith III, diSessa, \& Roschelle, 1994). Thus, misconceptions arise from consistently applying an incorrect rule or procedure and constitute a deeper level error. Errors in a broad sense include incorrect answers and flawed solutions, stemming from slips as well as underlying misconceptions (Olivier, 1992; Santagata \& Bray, 2015). In this research, we use this broad sense of error to encompass different respondents' interpretations of the word "error" when answering the open-ended questions in our questionnaire.

Errors in mathematics learning have been studied from many perspectives. These aspects include teacher attitudes towards their pupils' errors (Gagatsis \& Kyriakides, 2000); teacher knowledge about errors (Lin \& Tsai, 2013; Peng \& Luo, 2009); teacher response to errors (Kersting, Givvin, Thompson, Santagata, \& Stigler, 2012; Schleppenbach, Flevares, Sims, \& Perry, 2007; Son, 2013; Steuer, Rosentritt-Brunn, \& Dresel, 2013); students' views on errors (Lannin, Barker, \& Townsend, 2007) and classroom error climate ('O Dell, 2015; Steuer \& Dresel, 2015). Student errors have also been studied extensively (e.g. Booth, Barbieri, Eyer, \& Paré-Blagoev, 2014; Kapur, 2014; Nesher, 1987; Smith III et al., 1994) and students' beliefs have been found to be important in learning from errors (Tulis, Steuer, \& Dresel, 2017).

However, little research has focused on teachers' beliefs about the role of errors in learning mathematics. Tulis (2013) found that students easily copy their teacher's attitude towards mistakes (see also Stipek, Givvin, Salmon, \& 
MacGyvers, 2001), so more attention to these issues is due. As framed by Pehkonen (1998, 2009), beliefs can be both conscious or unconscious and cognitive or affective in nature, whereas attitudes are beliefs with emphasis on the affective. Therefore, we opt to speak about beliefs. Beliefs cannot be measured directly, but instead beliefs can be derived from what people think or do (Pajares, 1992). Thus, beliefs can be inferred by open questions asking what teachers think about errors.

\section{Research about teachers' error beliefs}

Let us review what is said about teachers' error beliefs in the research literature. We exclude the case when the teacher him/herself is committing the error.

Bray (2011) found that some teachers thought showing errors in whole-class discussions would embarrass or confuse students. This belief was related to avoiding discussions about errors. Teachers see students making errors in front of the class as harming students' self-confidence and self-esteem, and reducing students' willingness to share ideas with the class (Silver et al., 2005; Bray, 2011). Further, teachers see errors as distractions when handling a calculation at the blackboard and do not easily raise flawed solutions to whole class discussion (Bray, 2011)

Furthermore, classroom activity related to errors was influenced by teachers' general (non-error related) beliefs about students' ability to support one-another, answer-orientation and emphasis on conceptual understanding (Bray, 2011). If teachers think errors are something to be avoided, mathematics will be taught as step-by-step procedures. They avoid taking risks and forgo opportunities for conceptual understanding (Santagata, 2005; Bray, 2011). Also, avoiding dealing with errors may send a message to students to do the same (Ingram, Pitt, \& Baldry, 2015).

The collection of beliefs about errors has been called error orientation. In the context of organizational psychology, Rybowiak, Garst, Frese and Batinic (1999) developed a questionnaire on error orientation in the workplace and characterized it by eight dimensions. Matteucci, Corrazza, Santagata (2015) adapted and shortened this questionnaire for use with teachers. Sample items from both questionnaires are shown in Table 1, along with Cronbach's alphas (range 0.29-0.69) from the latter study. 
Table 1. Error orientation dimensions of Rybowiak et al. (1999) and Matteucci et al. (2015)

\begin{tabular}{lll} 
Category & Rybowiak et al. & Matteucci et al. \\
\hline $\begin{array}{l}\text { Error } \\
\text { competence }\end{array}$ & $\begin{array}{l}\text { I don't let go of the goal, al- } \\
\text { though I may make mistakes }\end{array}$ & $\begin{array}{l}\text { When a student does some- } \\
\text { thing wrong, I correct it imme- } \\
\text { diately }\end{array}$ \\
$\begin{array}{l}\text { Learning } \\
\text { from errors } \\
(\alpha=0.50)\end{array}$ & $\begin{array}{l}\text { Mistakes assist me to improve } \\
\text { my work }\end{array}$ & $\begin{array}{l}\text { Students' mistakes help me to } \\
\text { improve my work }\end{array}$ \\
$\begin{array}{l}\text { Error risk } \\
\text { taking } \\
(\alpha=0.69)\end{array}$ & $\begin{array}{l}\text { I'd prefer to err, than to do } \\
\text { nothing at all }\end{array}$ & $\begin{array}{l}\text { If one wants to achieve at } \\
\text { school, one has to risk making } \\
\text { mistakes }\end{array}$ \\
$\begin{array}{l}\text { Error } \\
\text { anticipation } \\
(\alpha=0.50)\end{array}$ & $\begin{array}{l}\text { I anticipate mistakes happen- } \\
\text { ing in my work }\end{array}$ & $\begin{array}{l}\text { In carrying out school tasks, } \\
\text { the likelihood of errors is high }\end{array}$ \\
$\begin{array}{l}\text { Thinking } \\
\text { about errors } \\
(\alpha=0.66)\end{array}$ & $\begin{array}{l}\text { When a mistake occurs, I } \\
\text { analyze it thoroughly }\end{array}$ & $\begin{array}{l}\text { I often think: "How could I } \\
\text { have prevented this"? }\end{array}$ \\
$\begin{array}{l}\text { Error } \\
\text { communica- } \\
\text { tion }(\alpha=0.55)\end{array}$ & $\begin{array}{l}\text { If I cannot manage to correct a } \\
\text { mistake, I can rely on others }\end{array}$ & $\begin{array}{l}\text { When a student makes a mis- } \\
\text { take, I tell others about it in } \\
\text { order that they do not make } \\
\text { the same mistake }\end{array}$ \\
$\begin{array}{l}\text { Error strain } \\
(\alpha=0.56)\end{array}$ & $\begin{array}{l}\text { I am often afraid of making } \\
\text { mistakes }\end{array}$ & $\begin{array}{l}\text { I find it stressful when a stu- } \\
\text { dent errs }\end{array}$ \\
$\begin{array}{l}\text { I do not find it useful to dis- } \\
\text { cuss my mistakes }\end{array}$ & $\begin{array}{l}\text { Why mention a mistake when } \\
\text { it isn't obvious? }\end{array}$ \\
& &
\end{tabular}

We believe that statements about coping with one's own errors cannot be transferred to statements about student's errors this easily (as reflected by the low Cronbach's alphas). For instance in the case of Error competence, the item proposed by Matteucci et al. (2015), "When a student does something wrong, I correct it immediately", has a different aspect than the original: it no longer concerns capability to correct the error but rather the teacher's pedagogical choices which may be influenced by factors such as the fear of shaming students reported by Silver et al. (2005) and Bray (2011). 
Upon finding such poor Cronbach's alphas for the earlier categories (Table 1), Matteucci et al. (2015) aggregated the items from all categories and performed a cluster analysis. This resulted in two groups of teachers (accounting for $78.3 \%$ of the sample) which they labeled positive and negative error orientation. The labels were based on a theoretical analysis of the items on which each group scored high, although Error communication was, to the surprise of the researchers, affiliated with negative error orientation.

\section{Intentional errors}

The context in the previous studies is that errors occur and the objective is to find out how teachers deal with them. For spontaneous errors this is understandable since (by definition) you do not plan ahead, but just react as errors appear. Intentional errors change this setup. Now teachers can plan to bring up an error for discussion, or choose not to.

Intentional errors enable the teacher to ensure that typical student errors are encountered, discussed and analyzed during a lesson. What we call intentional errors have been used in examples (Star et al., 2015) and called incorrect examples (Booth, Lange, Koedinger, \& Newton, 2013; Durkin \& Rittle-Johnson, 2012) or erroneous examples (Adams et al., 2014; Isotani et al., 2011). When emphasis is needed, we call those errors which are not intentional spontaneous errors.

Intentional errors are not typical in standard teaching material (Durkin \& Rittle-Johnson, 2012), but have led to some promising learning outcomes (Adams et al., 2014; Booth, Lange, Koedinger, \& Newton, 2013; Durkin \& Rittle-Johnson, 2012). It is more useful to compare incorrect and correct solutions than two correct ones, at least in the context of learning correct terminology and procedures for decimal numbers (Durkin \& Rittle-Johnson, 2012) and developing conceptual understanding of algebra (Booth et al., 2013). Analyzing erroneous examples led to better long-term results than merely studying correct examples (Adams et al., 2014). In one study, low-achievement students did not benefit from incorrect examples (Große \& Renkl, 2007) while in another all ability groups benefited (Booth et al., 2013).

In the previous section we described the few studies directly related to teachers' error beliefs, which will also be used when considering the validity of the results of this study. We study mathematics teachers' beliefs for using errors 
and intentional errors in teaching mathematics. To the best of our knowledge, noone has studied mathematics teachers' beliefs related to intentional errors. Our approach is qualitative and we aim to describe a wide range of teachers' reasons.

To obtain categories and items relevant in the teaching context, we collected open-ended responses from teachers regarding the use and usefulness of errors in mathematics teaching. Our research questions are:

RQ1. What reasons do teachers give for using or not using spontaneous and intentional errors in teaching?

RQ2. Are teachers inclined to use spontaneous errors and intentional errors in their teaching?

\section{Data}

Data was collected with an online questionnaire (Appendix 1). In this research we use the answers to the following two open-ended questions:

Q1. What role do you think errors have in learning mathematics?

Q2. Why do you use or not use intentional errors?

Since there was no mention of intentional errors prior to the first question, it is reasonable to assume that respondents mostly had in mind spontaneous errors when answering it, and in any case offer thoughts which apply to errors generally. In conjunction with the second question there was a brief explanation of what is meant by intentional error.

The questionnaire was sent to 50 middle-school mathematics teachers in Northern Finland of whom 23 answered. We gained $46 \%$ response rate which can be considered good since the response rate of online questionnaires is lower than with paper questionnaires (Nulty, 2008). Most respondents had more than ten years of teaching experience (65\%) and none had less than two years. Most $(61 \%)$ said that they seldom or never use intentional errors. Eleven of the respondents had used or were familiar with our Flexible Equation-solving (FES) material which included some intentional errors.

\section{Methods and analysis}

The data was analyzed qualitatively. Separate analyzes were used for the two research questions. Teachers' answers were handled sentence-wise. 
The first research question was approached by data-driven content analysis. The analysis was phenomenographically inspired. The purpose of phenomenography is to find "qualitatively different ways which people experience or conceptualize" a certain phenomenon (Marton, 1986; Syrjälä, Ahonen, Syrjäläinen, \& Saari, 1994). Different conceptions are categorized based on their meanings. The researcher's strong background information about the phenomenon is important in this process of understanding the answers and categorizing them. Categories are not pre-determined but constructed by the researcher during the process. To explain the difference of conceptions, initial categories are aggregated into higherorder categories of the meanings of the phenomenon. The main outcome of this method is a description of categories and their content (Marton, 1986). Reliability of the research can be estimated by the authenticity and relevance of both material and categories (Syrjälä et al., 1994).

For RQ1, one set of categories was derived from answers to both Q1 and Q2 without distinguishing from which question each sentence came. The motivation for this is that both types of answers contained information about reasons that teachers gave for using or not using errors in teaching and learning mathematics. The initial categorization was done by the first author. She was looking for different teacher beliefs about using errors and intentional errors. The QSR NVivo 10 software was used. After forming initial groups, she looked at connections between the groups to form categories. The categories were discussed by both authors and some revisions to the descriptions of the categories were made. Finally, the data was re-coded by both of the authors and disagreements were discussed and resolved.

The second research question was analyzed using extrinsic content analysis (Cohen, Manion, \& Morrison, 2007). This means that there were predetermined, in our case mutually exclusive, categories into which the sentences were divided. The purpose of content analysis is to generate compact description of phenomena and produce quantitative data from open ended answers.

We divided teachers' statements according to whether they are supportive of using errors in teaching or not. Matteucci et al. (2015) had error orientation categories labelled positive and negative but with slightly different meaning. For clarity, we call our categories Pro and Contra. The Pro category includes statements in which teachers endorse the use of errors, whereas the Contra category contains those statements wherein teachers express reservations or skepticism towards the usability of errors in teaching and learning of mathematics. Furthermore, we included a third category, Neutral, which contains statements which are 
either neutral or conditional towards errors. We used this distinction to compare teachers' beliefs toward errors and toward intentional errors in particular. Answers to Q1 and Q2 were distinguished: the number of sentences in each category was tallied separately for the two questions.

\section{Results}

Reasons for using or not using errors and intentional errors (RQ1)

In the initial round of the content analysis, answers were divided into 20 groups which covered a variety of different aspects of using errors. In the next stage, the groups were combined into the eight categories. Table 3 shows the categories and the number of sentences in each category from Q1 and Q2 as well as a succinct definition of the category and several sample sentences. For instance, $4+6$ in the Activation category means that four sentences originated from Q1 and eight from Q2, for a total of 12 sentences in this category. Some categories had only a few comments but the number of comments is not so relevant when looking for variety of aspects (Marton, 1986).

Some sentences were included in two different categories, e.g. Activation and discussion and Analyzing skills. Since positive and negative aspects were not differentiated in the analysis for the first research questions, some categories include both positive and negative comments. For instance, in the category (Mis)remembering errors, some teachers were afraid that students would remember and use the erroneous procedure whereas others stated that students are generally able to remember erroneous examples for what they are. The same applies to the (Mis)understanding errors category.

The sentences were classified into the categories independently by the two authors. The coders reached $98 \%$ agreement level and kappa coefficient 0.92 which is considered almost perfect agreement. After that, disagreements were resolved. The final numbers of answers in different categories are presented in Table 3.

Many categories were well represented in answers to both Q1 and Q2. Activation, Correcting misconceptions, (Mis)remembering and (Mis)understanding were slightly more prominent in Q2, whereas the opposite was the case for Analyzing skills. That Unspecific and Time relate to Q1 and Q2, respectively, is to be expected. Surprisingly, Learning to live with errors was only represented 
in answers to Q1. It is worth noting that all categories except Learning to live with errors are of a cognitive rather than affective nature.

Teachers' beliefs about using errors and intentional errors (RQ2)

Teachers' answers to the open questions were classified in the predetermined categories, Pro, Neutral and Contra, which have been described earlier in the section Method and analysis. The distribution of comments for both questions is shown in Table 2, where the teachers involved in the FES project and other respondents are distinguished.

Table 2. Summary of teachers' Pro \& Contra beliefs

$\begin{array}{llrrr} & \text { Teachers } & \text { Pro } & \text { Neutral } & \text { Contra } \\ \text { Q1 } & \text { FES } & 21 & 5 & 0 \\ & \text { Others } & 25 & 4 & 0 \\ \text { Q2 } & \text { FES } & 10 & 5 & 1 \\ & \text { Others } & 9 & 6 & 8\end{array}$

There were 46 Pro, 9 Neutral and 0 Contra sentences for Q1. For Q2 about intentional errors the corresponding numbers were 19,11 and 9. There was a difference on the Pro-Neutral-Contra axis between beliefs expressed in the two questions ( $p \approx 0.0001$ in $\chi^{2}$ test), which is not surprising given the different wordings. Teachers in this study had some reservations about using intentional errors (9 Contra comments). Examples of statements in different categories are given in Table 4.

FES teachers had either taken part in FES training or used FES material which included some intentional errors. FES teachers seem to have more positive beliefs (10 Pro, 5 Neutral and 1 Contra comments) about intentional errors than the other teachers (9 Pro, 6 Neutral and 8 Contra). However, the difference was not statistically significant ( $p \approx 0.1$ in $\chi^{2}$ test).

A diversity of positive beliefs was exposed in this analysis. For example, Pro beliefs were related to teachers seeing errors as learning opportunities, as possibilities to see difficulties and to test if the class is following the teaching. Contra comments were related to student confusion caused by the error. Some respondents stated that teachers must not present incorrect answers. Conditional/Neutral comments were related to the teachers' hesitations about using errors. Teachers thought that errors have pedagogical potential, but can confuse pupils. 
Table 3. Teachers' reasons to use (or not) errors and intentional errors

Category Description

(\# answers) Sample sentences

Activation Errors provide opportunities for students to take a more active and role in learning and classroom discussion

discussion To keep students awake

(4+6) [..] discuss where erroneous thinking comes from

Many students like to correct the teacher's errors

Analyzing Errors provide opportunities for students to develop skills for

skills

$(15+6)$

analyzing mathematical arguments and claims

They have to think where the error came from

I use errors which lead to contradictions

By looking at errors you have committed, you have to think about intermediate steps [...]

Correcting Errors can reveal misconceptions and therefore provide oppormisconcep- tunities to correct or prevent false knowledge

tions

$(5+10)$

[Errors] help to notice things and thinking models with some-

thing to correct

From my experience, I know that pupils make certain types of errors and I try to make them have a look at them

Learning to Errors provide opportunities to learn to cope with the feeling live with of having failed

errors (9+0) You learn [...] to work with the feeling that you have failed Everybody makes mistakes, including the teacher; it is not a disaster to fail

(Mis)re- Do students remember the erroneous nature of the presented membering errors errors?

Erroneous activity is often remembered as the right one If you make an error, you will probably remember it correctly next time

(Mis)under- Do students understand the erroneous nature of the presented standing errors?

errors $(3+9) \quad[.$.$] I make sure that everybody understood that there was an$ error at hand

Some students confuse right and wrong solution

Time $(0+2) \quad$ Errors cannot be used because of time constrains

There is so little time

Unspecific Statement about errors without rationale

$(17+5) \quad$ You learn from errors

There must not be any errors in the teacher's model solution 
Table 4. Examples of statements in the different categories

Pro You learn from errors and errors enable looking at how students think You can easily show where the pitfalls are, so you can be aware of them later on

It is mathematics to find out where you have made an error and how to fix it

To test how attentive the class is: "There is an error in this calculation, who can find it?"

To highlight pitfalls of mechanical counting

Neutral The error itself is not a bad thing but errors should be removed as soon as possible

They [errors] are pedagogical if the result leads to a contradiction [Errors] help students figure out the right thing but errors can confuse low-achieving students

I don't want students to get the wrong method in their head. When I use intentional errors, I make sure that everybody understands that it is indeed an error

Contra Often an erroneous method stays as a correct method in students' minds

I don't want students to have erroneous ways of counting in their mind

There is so little time and unfortunately intentional errors stay as a right solution model in some students' mind

\section{Discussion}

Validity of content analysis and especially phenomenographical analysis can be estimated by how the categories were found and described (Cohen, Manion, \& Morrison, 2007; Marton, 1986). The clarity of the category descriptions is supported by the high inter-rater agreement in the independent classification. Our questionnaire did not necessarily stimulate long responses: some answers were rich whereas others were quite short and written as bullet-points. This also plays a role when evaluating the validity and representativeness of the results. Finally, results can be validated by comparing categories obtained with previous research, which is what we turn to next. 


\section{Relation to studies by Matteucci et al. (2015)}

The closest previous studies are by Rybowiak et al. (1999) and Matteucci et al. (2015). They deal with error orientation in a work and a teaching environment, respectively. In the literature review we have already argued that the error orientations found in the work environment may not be suitable to the teaching context. Here we compare these error orientations with the findings of this study.

Table 5 indicates the eight dimensions of error orientation from Matteucci et al. (2015). Also, where applicable, the table shows a statement from a teacher in our study which illustrates the category in a teaching context. Also shown are the Cronbach $\alpha$ from the study of Matteucci et al. (2015).

As can be seen from Table 5, six of the eight categories proposed by Matteucci et al. (2015) were evident in our data. We did not find statements related to the categories Error strain and Error competence. On the other hand, Correcting misconceptions, (Mis)remembering errors and Time did not correspond to any error orientation from the previous study.

Furthermore, Analyzing skills and Learning to live with errors were each connected to two error orientations, namely Learning from errors and Thinking about errors, and Error risk taking and Error anticipation, respectively. It is also worth noting that Error strain is to some extent the inverse of the category Learning to live with errors, in the sense that high Error strain corresponds to a lack of Learning to live with errors.

In the literature review, we already suggested that the Error competence category was "contaminated" by a new affective dimension in the teaching context. This is corroborated by the fact that no teacher statements in this study fit into this category.

Error strain was not plagued by quite so low an $\alpha$, but was still not found in our data. In this case the category seems sound; the reason teachers did not mention such issues is probably that their statements were heavily focused on cognitive aspects rather than affective ones. Only the category Learning to live with errors is affective in nature, and in this category teachers mostly espoused optimistic views. In contrast, previous studies found teachers to be afraid that errors may embarrass students and harm their self-confidence (Silver et al., 2005; Bray, 2011). Based on anecdotal evidence, such reactions could be expected also from Finnish teachers. It is not clear why they were absent in the current study.

Developing class error culture has been suggested as an important factor in learning mathematics ('O Dell, 2015; Steuer \& Dresel, 2015; Steuer et al., 2013). 
Table 5. Error orientation dimensions of Matteucci et al. (2015)

\begin{tabular}{|c|c|c|c|}
\hline $\begin{array}{l}\text { Category in } \\
\text { Matteucci } \\
\text { et al. }\end{array}$ & $\begin{array}{l}\text { Matteucci et al. - sam- } \\
\text { ple item }\end{array}$ & $\begin{array}{l}\text { This study — sample } \\
\text { sentence }\end{array}$ & $\begin{array}{l}\text { Category in } \\
\text { this study }\end{array}$ \\
\hline $\begin{array}{l}\text { Error } \\
\text { competence } \\
(\alpha=0.29)\end{array}$ & $\begin{array}{l}\text { When a student does } \\
\text { something wrong, I cor- } \\
\text { rect it immediately }\end{array}$ & & \\
\hline $\begin{array}{l}\text { Learning } \\
\text { from errors } \\
(\alpha=0.50)\end{array}$ & $\begin{array}{l}\text { Students' mistakes help } \\
\text { me to improve my work }\end{array}$ & $\begin{array}{l}\text { Errors improve learning } \\
\text { because they force you to } \\
\text { think }\end{array}$ & $\begin{array}{l}\text { Analyzing } \\
\text { skills }\end{array}$ \\
\hline $\begin{array}{l}\text { Error risk } \\
\text { taking } \\
(\alpha=0.69)\end{array}$ & $\begin{array}{l}\text { If one wants to achieve } \\
\text { at school, one has to risk } \\
\text { making mistakes }\end{array}$ & $\begin{array}{l}\text { If you don't have the } \\
\text { courage to make errors, } \\
\text { you are not able to do } \\
\text { anything at all }\end{array}$ & $\begin{array}{l}\text { Learning } \\
\text { to live with } \\
\text { errors }\end{array}$ \\
\hline $\begin{array}{l}\text { Error } \\
\text { anticipation } \\
(\alpha=0.50)\end{array}$ & $\begin{array}{l}\text { In carrying out school } \\
\text { tasks, the likelihood of } \\
\text { errors is high }\end{array}$ & $\begin{array}{l}\text { Everybody makes mis- } \\
\text { takes, including the } \\
\text { teacher }\end{array}$ & $\begin{array}{l}\text { Learning } \\
\text { to live with } \\
\text { errors }\end{array}$ \\
\hline $\begin{array}{l}\text { Thinking } \\
\text { about } \\
\text { errors } \\
(\alpha=0.66)\end{array}$ & $\begin{array}{l}\text { I often think: "How could } \\
\text { I have prevented this"? }\end{array}$ & $\begin{array}{l}\text { By exploring your errors } \\
\text { you have to think about } \\
\text { intermediate steps }\end{array}$ & $\begin{array}{l}\text { Analyzing } \\
\text { skills }\end{array}$ \\
\hline $\begin{array}{l}\text { Error com- } \\
\text { munication } \\
(\alpha=0.55)\end{array}$ & $\begin{array}{l}\text { When a student makes } \\
\text { a mistake, I tell others } \\
\text { about it in order that } \\
\text { they do not make the } \\
\text { same mistake }\end{array}$ & $\begin{array}{l}\text { Together we look at erro- } \\
\text { neous solution and find } \\
\text { where the error came } \\
\text { from }\end{array}$ & $\begin{array}{l}\text { Activation } \\
\text { and discus- } \\
\text { sion }\end{array}$ \\
\hline $\begin{array}{l}\text { Error strain } \\
(\alpha=0.56)\end{array}$ & $\begin{array}{l}\text { I find it stressful when a } \\
\text { student errs }\end{array}$ & & \\
\hline $\begin{array}{l}\text { Covering } \\
\text { up errors } \\
(\alpha=0.40)\end{array}$ & $\begin{array}{l}\text { Why mention a mistake } \\
\text { when it isn't obvious? }\end{array}$ & $\begin{array}{l}\text { I avoid errors because } \\
\text { they can confuse pupils }\end{array}$ & $\begin{array}{l}\text { (Mis)un- } \\
\text { derstanding } \\
\text { errors }\end{array}$ \\
\hline
\end{tabular}

Our category Learning to live with errors is the expression of positive class error culture on the individual level.

Our final comments concern Error communication. Matteucci et al. (2015) were surprised that this category was connected to negative error orientation in the cluster analysis. We found that several categories were bidirectional, e.g. 
(Mis)understanding errors, and it may be that the same applies to Error communication: the risk of miscommunication could be greater at school than at work. This may be a reason for the surprising link of communication to negative error orientation in Matteucci et al. (2015).

Teachers' reasons to use or not to use errors and intentional errors

Our content driven analysis exposed seven categories of teachers' reasons to use or not to use errors. Bray (2011) found that teachers considered errors a distraction when presenting solutions. Based on our data, we can refine this reason into two parts:

- Errors may be a distraction, because students to not understand in the first place that there is an error or where it is.

- Students may have initially understood the error, but the awareness of the error is missing when they try to recall or apply the knowledge later on.

Beliefs related to this distinction have not been previously found in studies with mathematics teachers, to the best of our knowledge. Many teachers in this study were aware of the possibility of distraction mentioned above, but had a more optimistic view that students are able to overcome the difficulties. This optimistic view corresponds to the other pole in the categories, Remembering errors and Understanding errors.

Additionally, teachers in our study saw many aspects which presenting errors could promote: activation and discussion, analyzing skills, correcting misconceptions and learning to live with errors. These beliefs are consistent with researchers' views (e.g., Borasi, 1994; Bray \& Santaga, 2014) on the potential of errors in learning. Surprisingly, the Learning to live with errors category was proposed 9 times as something one can learn from errors (Q1), but not a single time was it given as a reason why one might use intentional errors (Q2).

Since research has shown that affect plays a major role when dealing with errors (Bray, 2011; Silver et al., 2005), this indicates that the teachers in this study may not have had a complete understanding of all the elements that are relevant for successfully using errors. Also on the affective side, the fact that erroravoidance sends a message to students that errors should be avoided (Ingram et al., 2015) was not brought up by the teachers in this study.

Teachers' answers concentrated on the Pro category, especially for errors generally. When asked about intentional errors, teachers had some reservations, a finding paralleled by Durkin and Rittle-Johnson (2012). The difference between 
these beliefs may be due to unfamiliarity with intentional errors, as exposure to error-handling leads to more positive views on use of errors (Matteucci et al., 2015). Teachers in the Flexible Equation-solving Project had heard about the idea and seemed to have fewer reservations, which supports this explanation.

\section{Conclusions}

As best we know, this is the first study to consider mathematics teacher beliefs in the context of intentional errors. We found that this was a meaningful issue, since teachers' answers to the question concerning intentional errors seemed to differ from their answer regarding errors generally, and showed new aspects of their thinking about errors.

Teachers in this study had a generally favorable view on errors in teaching and learning mathematics. They identified errors' potential for activation and discussion, developing analytical skill and correcting misconceptions. These functions have also been proposed in the literature. Based on the responses, we were also able to discern distinctions between risk/potential of (Mis)understanding errors and (Mis)remembering errors. Both categories, especially the former, were evident mainly in responses to the intentional error question, and the distinction might not have been found without it.

We were interested to know what makes mathematics teachers not adopt intentional error tasks. According to these results, teachers may be afraid of time constraints or of confusing students with an (intentional) errors which may be either misremembered or misunderstood. On the other hand, this study revealed many positive aspects in using errors which could be emphasized in teaching material or professional development courses on intentional errors.

The generally positive view of the teachers in this study provides an encouraging outlook for introducing tasks with intentional errors into classrooms. However, some caveats should be mentioned. First, the sample of teachers was small and likely biased by the inclusion of an above-average number of active teachers. Teachers emphasized cognitive aspects and seemed surprisingly oblivious to the risk of harm to student self-confidence. Teachers did mention that working with errors makes one better able to live with them, however. Further, if teachers do not anticipate students' negative affective reactions, then they may be taken aback by student resistance to new modes of working. Then the intentional-error tasks may be discarded before students and teachers have had a chance to learn how to study with them. 
This research also led to several questions. Is there a difference between how teachers' see the role of errors and intentional errors? How do our categories pertain to different teachers? How does teacher training effect teachers' valuing errors? The categories found in this study will be used in a quantitative questionnaire which can be used with a larger sample of teachers to obtain representative results addressing some of these questions.

\section{Acknowledgements}

The first author was supported by the Jenny and Antti Wihuri Foundation, OKKA Foundation, UniOGS, MAOL and Exactus.

\section{References}

[1] Adams, D. M., McLaren, B. M., Durkin, K., Mayer, R. E., Rittle-Johnson, B., Isotani, S., \& Van Velsen, M., Using erroneous examples to improve mathematics learning with a web-based tutoring system, Computers in Human Behavior $\mathbf{3 6}$ (2014), 401-411. DOI: 10.1016/j.chb.2014.03.053.

[2] Booth, J. L., Barbieri, C., Eyer, F., \& Paré-Blagoev, E. J., Persistent and pernicious errors in algebraic problem solving, Journal of Problem Solving 7, no. 1 (2014), 10-23. DOI: 10.7771/1932-6246.1161.

[3] Booth, J. L., Lange, K. E., Koedinger, K. R., \& Newton, K. J., Using example problems to improve student learning in algebra: Differentiating between correct and incorrect examples, Learning and Instruction 25 (2013), 24-34. DOI: 10.1016/j.learninstruc.2012.11.002.

[4] Borasi, R., Capitalizing on errors as "springboards for inquiry": A teaching experiment, Journal for Research in Mathematics Education 25, no. 2 (1994), 166-208.

[5] Bray, W. S., A collective case study of the influence of teachers' beliefs and knowledge on error-handling practices during class discussion of mathematics., Journal for Research in Mathematics Education 42, no. 1 (2011), 2-38. DOI: 10.5951/jresematheduc.42.1.0002.

[6] Bray, W. \& Santagata, R., Making mathematical errors "springboards for learning", Annual Perspectives in Mathematics Education (APME): Using research to improve instruction, Reston, VA, USA: National Council of Teachers of Mathematics (2014).

[7] Brodie, K., Learning about learner errors in professional learning communities, Educational Studies in Mathematics 85, no. 2 (2014), 221-239. DOI: 10.1007/s10649-013-9507-1.

[8] Cohen, L., Manion, L., \& Morrison, K., Research Methods in Education, Abingdon, UK: Routledge, 2007. 
[9] Durkin, K. \& Rittle-Johnson, B., The effectiveness of using incorrect examples to support learning about decimal magnitude, Learning and Instruction 22, no. 3 (2012), 206-214. DOI: 10.1016/j.learninstruc.2011.11.001.

[10] Gagatsis, A. \& Kyriakides, L., Teachers' attitudes towards their pupils' mathematical errors, Educational Research and Evaluation 6, no. 1 (2000), 24-58. DOI: 10.1076/1380-3611(200003)6.

[11] Große, C. S. \& Renkl, A., Finding and fixing errors in worked examples: Can this foster learning outcomes?, Learning and Instruction 17, no. 6 (2007), 612-634. DOI: 10.1016/j.learninstruc.2007.09.008.

[12] Ingram, J., Pitt, A., \& Baldry, F., Handling errors as they arise in whole-class interactions, Research in Mathematics Education 17, no. 3 (2015), 183-197. DOI: 10.1080/14794802.2015.1098562.

[13] Isotani, S., Adams, D., Mayer, R. E., Durkin, K., Rittle-Johnson, B., \& McLaren, B. M., Can erroneous examples help middle-school students learn decimals?, Lecture Notes in Computer Science 6964 LNCS (2011), 181-195. DOI: 10.1007/978-3-642-23985-4_15.

[14] Kapur, M., Productive failure in learning math, Cognitive Science 38, no. 5 (2014), 1008-1022. DOI: 10.1111/cogs.12107.

[15] Kersting, N. B., Givvin, K. B., Thompson, B. J., Santagata, R., \& Stigler, J. W., Measuring usable knowledge: Teachers' analyses of mathematics classroom videos predict teaching quality and student learning, American Educational Research Journal 49, no. 3 (2012), 568-589. DOI: 10.3102/0002831212437853.

[16] Lannin, J. K., Barker, D. D., \& Townsend, B. E, How students view the general nature of their errors, Educational Studies in Mathematics 66 (2007), 43-59. DOI: 10.1007/s10649-006-9067-8.

[17] Lin, P. \& Tsai, W., Enhancing pre-service teachers' knowledge of students' errors by using research-based cases, Proceedings of the 37th Conference of the International Group for the Psychology of Mathematics Education 3 (2013), 273-280.

[18] Marton, F., Phenomenography - a research approach to investigating different understandings of reality, Journal of Thought 21, no. 3 (1986), 28-49.

[19] Matteucci, M. C., Corrazza, M., \& Santagata, Learning from errors, or not. Analysis of teachers' beliefs about errors and error-handling strategies through questionnaire and video, in: Progress in Education, Volume 37, Chapter: 3, (R.V. Nata, ed.), Nova Science Publishers, Hauppauge, NY, 2015.

[20] Metcalfe, J., Learning from errors, Annual Review of Psychology 68 (2017), 465-489. DOI:10.1146/annurev-psych-010416-044022.

[21] Nesher, P., Towards an instructional theory: the role of student's misconceptions, For the Learning of Mathematics 7, no. 3 (1987), 33-40.

[22] Nulty, D. D., The adequacy of response rates to online and paper surveys: what can be done?, Assessment and Evaluation in Higher Education 33, no. 3 (2008), 301-314. DOI: 10.1080/02602930701293231. 
[23] O'Dell, S., Classroom error climate: teacher professional development to improve student motivation, EdD Thesis. Orlando, FL, USA: University of Central Florida, 2015 .

[24] Olivier, A., Handling pupils' misconceptions, in: Mathematics education for pre-service and in-service, (M. Moodley, R.A. Njisani \& N. Presmeg, eds.), Shuter \& Shooter, Pietermaritzburg, South Africa, 1992, 193-209.

[25] Pajares, M. F., Teachers' beliefs and educational research: Cleaning up a messy construct, Review of Educational Research 62, no. 3 (1992), 307-332. DOI: 10.3102/00346543062003307.

[26] Palkki, R., Virheellinen esimerkki matematiikan luokkahuonekeskustelussa., in: Proceedings of Annual Symposium of the Finnish Mathematics and Science Education Research Association 2015, (H. Silfverberg \& P. Hästö, eds.), Finnish Mathematics and Science Education Research Association., Turku, Finland, 2016.

[27] Pehkonen, E., On the concept "mathematical belief", in: The state-of-art in mathematics-related belief research: Results of the MAVI activities 195, (E. Pehkonen \& G. Törner, eds.), University of Helsinki, Helsinki, Finland, 1998, 37-72.

[28] Pehkonen, E., Use of the Dionné tri-division to reveal teacher students' beliefs in mathematics, in: Proceedings of the conference MAVI-15: Ongoing research on beliefs in mathematics education, (F. Furinghetti \& F. Morselli, eds.), University of Genova, Genova, Italy, 2009.

[29] Peng, A., \& Luo, Z., A framework for examining mathematics teacher knowledge as used in error analysis, For the Learning of Mathematics 29, no. 3 (2009), 22-25.

[30] Rybowiak, V., Garst, H., Frese, M., \& Batinic, B., Error orientation questionnaire (EOQ): Reliability, validity, and different language equivalence, Journal of Organizational Behavior 20, no. 4 (1999), 527-547.

[31] Santagata, R., Practices and beliefs in mistake-handling activities: A video study of Italian and US mathematics lessons, Teaching and Teacher Education 21, no. 5 (2005), 491-508. DOI: 10.1016/j.tate.2005.03.004.

[32] Santagata, R., \& Bray, W., Professional development processes that promote teacher change: The case of a video-based program focused on leveraging students' mathematical errors, Professional Development in Education 42, no. 4 (2015), 547-568. DOI: 10.1080/19415257.2015.1082076.

[33] Schleppenbach, M., Flevares, L. M., Sims, L. M., \& Perry, M., Teachers' responses to student mistakes in Chinese and U.S. mathematics classrooms, The Elementary School Journal 108, no. 2 (2007), 131-147. DOI: 10.1086/525551.

[34] Silver, E., Ghousseini, H., Gosen, D., Charalambous, C., \& Strawhun, B. T. F., Moving from rhetoric to praxis: Issues faced by teachers in having students consider multiple solutions for problems in the mathematics classroom, Journal of Mathematical Behavior 24, no. 3 (2005), 287-301. DOI: 10.1016/j.jmathb.2005.09.009.

[35] Smith III, J. P., diSessa, A., \& Roschelle, J., Misconceptions reconceived: A constructivist analysis of knowledge in transition, Journal of the Learning Sciences 3, no. 2 (1994), 115-163. DOI: 10.1207/s15327809jls0302_1. 
[36] Son, J. W., How preservice teachers interpret and respond to student errors: Ratio and proportion in similar rectangles, Educational Studies in Mathematics 84, no. 1 (2013), 49-70. DOI: 10.1007/s10649-013-9475-5.

[37] Star, J. R., Pollack, C., Durkin, K., Rittle-Johnson, B., Lynch, K., Newton, K., \& Gogolen, C., Learning from comparison in algebra, Contemporary Educational Psychology 40 (2014), 41-54. DOI: 10.1016/j.cedpsych.2014.05.005.

[38] Steuer, G., \& Dresel, M., A constructive error climate as an element of effective learning environments, Psychological Test and Assessment Modeling 57, no. 2 (2015), 262-275.

[39] Steuer, G., Rosentritt-Brunn, G., \& Dresel, M., Dealing with errors in mathematics classrooms: Structure and relevance of perceived error climate, Contemporary Educational Psychology 38, no. 3 (2013), 196-210. DOI: 10.1016/j.cedpsych.2013.03.002.

[40] Stipek, D. J., Givvin, K. B., Salmon, J. M., \& MacGyvers, V. L., Teachers' beliefs and practices related to mathematics instruction, Teaching and Teacher Education 17, no. 2 (2001), 213-226. DOI: 10.1016/S0742-051X(00)00052-4.

[41] Syrjälä, L., Ahonen, S., Syrjäläinen, E., \& Saari, S., Laadullisen tutkimuksen työtapoja, Kirjayhtymä Oy, Helsinki, 1994.

[42] Tulis, M., Error management behavior in classrooms: Teachers' responses to student mistakes, Teaching and Teacher Education 33 (2013), 56-68. DOI: 10.1016/j.tate.2013.02.003.

[43] Tulis, M., Steuer, G., \& Dresel, M., Positive beliefs about errors as an important element of adaptive individual dealing with errors during academic learning, Educational Psychology 38, no. 2 (2017), 1-20. DOI: 10.1080/01443410.2017.1384536.

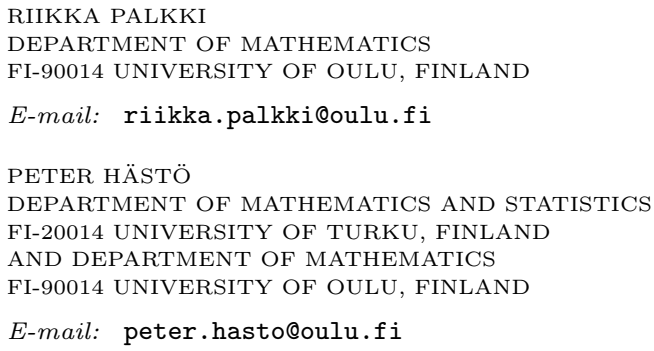


Appendix. The questionnaire (originally an online questionnaire in Finnish)

1. How many years of experience do you have teaching mathematics? Less than 6 months

6 months to less than a year

1 year to less than 2 years

2 years to less than 10 years

10 years to less than 20 years

2. What role do you think errors have in learning mathematics?

3. In a mathematics lesson, a pupil can make a mistake for example at the black board, answering the teacher?s question, working on his/her own with the notebook or working with other pupils. How do you act (would like to act) in these kinds of situations?

4. How often do you use intentional errors (e.g. show erroneous way to solve a task)?

Never

Seldom

Sometimes

Often

5. Why do you use or not use intentional errors?

(Received August, 2018) 